\title{
Ethical Aspects of Intertemporal Discounting and the Social Discount Rate*
}

\author{
Márta Somogyvári
}

The paper examines the ethical aspects of discounting during the preparation of intertemporal decisions, and the influence of this on the cost-benefit analysis of community investments. It focuses on the economic philosophy and ethical considerations that underlie discounting as a daily financial activity. The author attempts to resolve the apparent logical contradiction between the cardinal and discounted utilitarian ethical approaches. By analysing the preconditions related to the definition of the values of the parameters included in the Ramsey formula, it is presented that neither the social discount rate applied in the case of intertemporal investments nor the current practice of establishing the market discount rate used for investments representing a potential burden on the environment is suitable for the assessment of the long-term community investments and private investments burdening the environment.

Journal of Economic Literature (JEL) codes: A13, D63, H43, Q58

Keywords: discounting, social discount rate, Ramsey formula, utilitarianism, economic ethics

\section{Introduction}

Although economic and business decisions are seemingly about the future, in fact policy-makers are guided by a relatively static vision corresponding to or easily deducible from the present. This is the foreseeable and predictable future, where the cycles are repeated, trends continue, trend changes can be easily predicted, and disasters are moderate and negligible over the long run. By contrast, there are the situations which involve large, unpredictable changes even over the short run, and we do not know whether the scenario in store will be the one we imagined or something completely different. This second group also includes cases which involve such long-term periods of time the general conditions of which we are unable - or do not dare - to estimate. We tend to ignore the fact that the unforeseeable and

\footnotetext{
* The papers in this issue contain the views of the authors which are not necessarily the same as the official views of the Magyar Nemzeti Bank.

Márta Somogyvári is an Associate Professor in the Department of Quantitative Management of the Faculty of Business and Economics, University of Pécs. E-mail: somogyv@ktk.pte.hu

The Hungarian manuscript was received on 19 March 2018.

DOI: http://doi.org/10.25201/FER.17.3.109132
} 
unpredictable future - which we instinctively identify with the very long term - may appear on our time horizon even within a few years.

Why is it important to differentiate between the two types of future? Because, when economists talk about decisions impacting the future - whether foreseeable or unforeseeable - almost instinctively rely on the same tool, i.e. on discounting. According to the classic economic approach we can talk about risk when we are able to quantify the respective factor, while in the case of uncertainty we are unable to measure the probability and/or the outcome is fully uncertain (Knight 1921). The daily practice of investment valuation conflicts with these two, theoretically easily differentiable, notions. Discounting involves cash flows, which means that somebody somehow - either on an "objective" or "subjective" basis (Bélyácz 2010) - has already estimated the respective factor, be it the income earned in the 20th year as a result of the investment, or the rate of the inflation influencing the cost over the entire investment horizon. Neither of these are foreseeable, but nevertheless we estimate both of them to declare whether or not the investment will generate a return. And we try to clear up the uncertainties by discounting. Thus, discounting is an answer to the question "how to manage the future", and at the same time it is an easily usable, practical guideline for the preparation of financial calculations. The general response provided by discounting sounds like this: let us try to treat it as the present, just reduce its value a little bit. What may be surprising for an outsider is that in the case of both the foreseeable and the seemingly foreseeable future, which may become unforeseeable at any moment, most of the theoretical and practical trains of ideas rely on the same solution.

The standard discounting methods are used routinely in the elaboration of policies and measures applicable to the foreseeable future. The mechanism of discounting is the same as that of compound interest. However, while compound interest may be reasonably conceivable for the experts over the short run, over the long run it can generate results which appear unrealistic even for such experts. Consider, for example, the fact that a sum of USD 1,000 invested 100 years ago at a compound interest rate of 5 per cent would be worth USD 131,501 today. The same example would not work with the Hungarian forint, since the bank of 100 years ago would no longer exist (which in the case of the USA would be realistic), and 100 years ago the currency was also different, since meanwhile currency replacements, hyperinflation, economic crises, political transformations and various other disasters added colour to the economic conditions of Hungary.

In the case of the unforeseeable future, discounting raises questions even for those who use it as daily practice, since such mechanical devaluation of the future raises the issue of conflicts between the present and future generations. Seeing that over the long run a change even in a relatively small discount rate can cause major differences in the valuation of future cash flows, we have a good reason to assume 
that this calculation method is biased and it conflicts with our instincts, and perhaps also with common sense.

Discounting appears to be only as a secondary financial technical decision and its use is routine. It is exactly this lack of sophistication that conceals the fact that discounting and the discount rate fundamentally influence our decisions on the planning of investments necessary for the production public and private goods, and decide which investments should be implemented and which ones should be declared unprofitable.

The impact of discounting on the unforeseeable future can be best demonstrated by the cost-benefit analysis of measures related to climate change. Although we do not know the exact scenario in which climate change will materialise, we assume that it will generate losses both at the level of the individual national economies and globally. When Stern (2007), and a little bit later Nordhaus (2008), tried to take stock of these potential economic impacts, they used the same benchmark assumptions with regard to the impacts of the climate change, the determinant factors and key parameters of the economic system (Weisbach - Sunstein 2009). The largest difference between them is a seemingly minor technical issue, namely, the way they define the discount rate. Stern proposed a low, 1.4 per cent discount rate (later on he raised it to 2 per cent), while Nordhaus argued for a high, 5.5 per cent discount rate. The two values represent two different assessment of the future. When using a discount rate of 1.4 per cent, the costs of climate change 100 years later are 53-times higher than when using 5.5 per cent. 200 years later there is already a 2,800-fold difference (Weisbach - Sunstein 2009). The two authors propose different measures for preventing the impacts of climate change. Stern believes that immediate, expensive measures should be taken to reduce emissions of greenhouse gases and prevent losses. By contrast, Nordhaus takes the position that no quick measures are needed since the very low discount rate underlying those is not compatible with today's market conditions (Nordhaus 2006). In his opinion, a slow, gradual transformation of the energy framework is sufficient. Fast and instant measures are extremely expensive, offering relatively low profit.

\section{Impact of discounting on projects with asymmetric cost structure}

The discounting of the unforeseeable future is particularly interesting in the case of investments with a long life cycle, where the distribution of the costs and revenues during the service life is asymmetric. For example, when we evaluate certain energy production technologies, in calculating the net present value projects with high initial investment costs followed by low operation, maintenance and dismantling costs are disadvantaged compared to projects where the distribution of costs is more even. This difference systematically appears between investments based on renewable sources (wind, water, solar, geothermal) and fossil fuels (coal, gas, oil). 
When this financial valuation is accompanied by a moral judgement, according to which fossil fuels are "bad" and renewables are "good", everyone calls for aid to counterbalance the barriers to the renewable energies' market entry. High subsidies are justified in the case of immature technologies in the phase of innovation, if society believes that it wants to change over to another energy paradigm. When these technologies become mature, i.e. they are able to generate electricity at the same or even lower price as the network price, or the investment in the respective project has already returned, and the subsidy can be already interpreted as a rent. This rent is unearned compensation, which prevents society from using its resources for the implementation of other innovations or other social goals.

When assessing the burdens on future generations, investments burdening the environment in the future, where the costs of dismantling are extremely high, represent a special case. Figure 1 shows that in the case of projects of different lifetimes what proportion of the dismantling costs should be taken into consideration for the purpose of calculating the net present value of the project when applying different discount rates.

Figure 1

Proportion of dismantling costs taken into consideration for the purpose of the financial valuation of the project

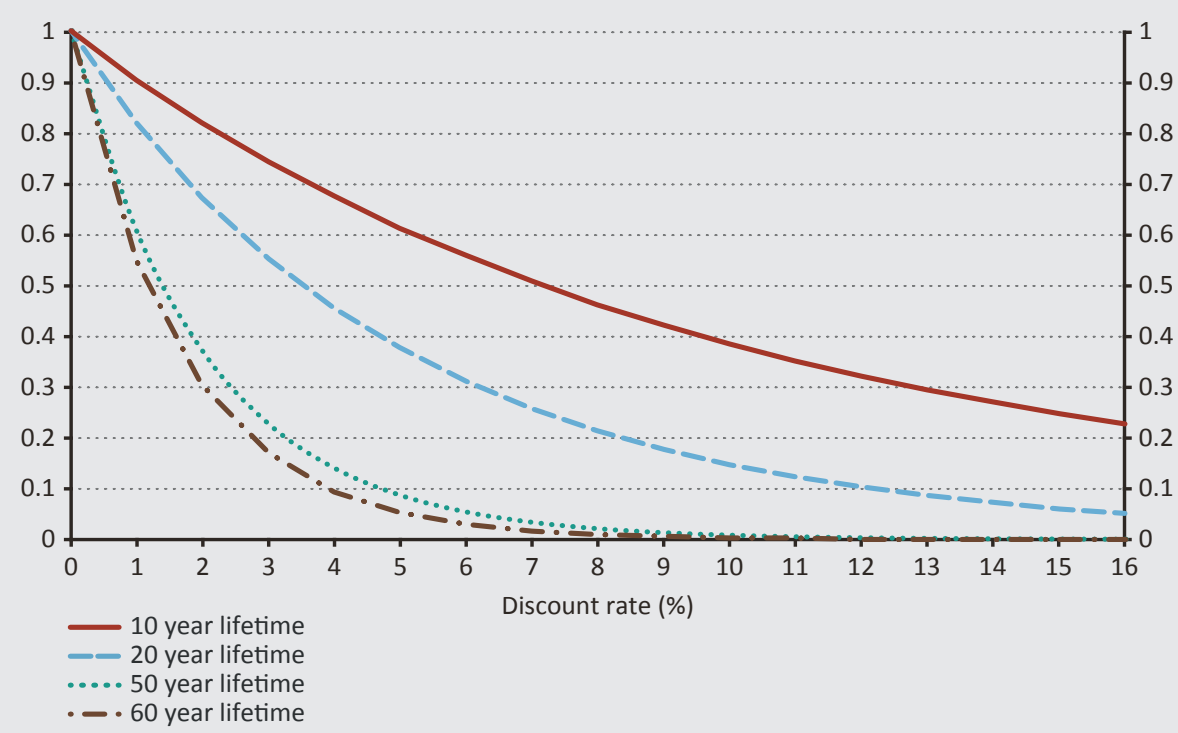


If the valuation of the project is for a lifetime of ten years, we see on the top curve that upon using a 2 per cent discount rate, 82 per cent of the dismantling costs are taken into consideration for the purpose of financial valuation. (If this amount is HUF 1 billion, the net present value of this is HUF 800 million.) With an increase in the lifetime and/or the discount rate, the dismantling cost taken into consideration for the investment decision becomes increasingly negligible. There are a number of industries where dismantling costs are high, because the machinery, areas or buildings used for the investment cannot be utilised for other purpose and/or are harmful for the environment (e.g. shutdown of mines, power stations or chemical plants). In this case, when the lifetime planned for the long run, i.e. 50-60 years, is accompanied by a discount rate of 4-5 per cent, it means that the burden of dismantling is hardly or not at all taken into consideration for the purpose of the investment decisions and we charge it to the future generation in full. In this case, uncertainty and ignorance of the future generations' plans are combined. We are uncertain in respect of the future costs, but instead of admitting this, we opt for a seemingly "technical" method that makes the future events financially unimportant. The policy-makers making the final decision, including economic experts or politicians financing the investments, are usually not aware of the fact that the verdict declaring an investment profitable is substantially influenced by the choice of the discount rate.

In discounting the cash flows of the distant future, the correlation illustrated in the figure above always exists, irrespective of whether it is a private or public investment. The German nuclear power plants were private investments, while the investment in the Hungarian nuclear power plant was financed by the Hungarian state. Dismantling costs exist in both cases, and it is almost impossible to assess the magnitude of those, since the highly radioactive waste must be stored at safe locations for periods of several hundred thousand years. But even if we ignore the storage costs, the direct costs of dismantling, neutralisation and disposal alone involve such high amounts that will be paid not by the individual (private or public) companies, but by the society in both cases. According to the Expert Committee of Sciences operating under the Parliament of the Federal Republic of Germany, the preliminarily estimated costs of dismantling will not be covered by the reserves appropriated in the balance sheets of the German energy companies, which, by the way, for the time being represent only a commitment rather than realistically appropriated funds (BWE 2015). This example also shows that in the case of the intertemporal decisions - for 40-50 years or for an even longer time horizon - the discount rate has the same effect irrespective of whether it involves a public or private investment. In both cases, with a sufficiently high discount rate, the burden of dismantling is shifted to future generations, while projects are also implemented which with a very low or even zero discount rate would be regarded as financially unviable. 


\section{Descriptive and prescriptive procedures for establishing the discount rate}

The procedures applied for determining the optimal discount rate differ based on the type of project. There are various methods for identifying the discount rate both in the case of private investments and public investments which are deemed important by society but fail the test of general market conditions and payback criteria. Essentially, two methods can be differentiated. The first group includes the methods that calculate the discount rate based on the observation of certain economic processes (descriptive, positive methods), while in the second group the definition of the discount rate is governed by express moral principles (normative, prescriptive methods).

\subsection{Observing the discounting habits of people}

Through a number of experiments behavioural economics has established that people primarily prefer the present and very strongly discount anticipated future rewards. This behaviour characterises almost all living organisms and is not only a determinant of human behaviour. This high degree of individual impatience may also be attributable to the fact that we cannot be sure that we still will be alive when we are able to reap the future profit or bear the future costs (Lewandowsky et al. 2017). This is also supported by the analysis of Trostel and Taylor (2001), which is based on panel data of household consumption habits in the USA (Panel Study of Income Dynamics - PSID). The authors concluded that the willingness to discount is not constant in the various phases of human life, and the older people are (the closer they believe to be to death), the more inclined they are to discount the future more strongly.

The discounting willingness of people is not necessarily linear, as it does not assess all future events and consumption opportunities in the same way. The concept of hyperbolic discounting describes the phenomenon - observed in the case of savings, borrowing, or even with sports or drug addiction - that people use a future valuation pattern - which can be best depicted by a hyperbolic curve - according to which they are impatient when it comes down to the present (i.e. short term) and patient about the future (cf. Rambaud - Torrecillas 2006).

\subsection{Discount rate determined based on the observation of capital markets and competitive market processes}

For the purpose of determining the discount rate used for private investments, a large number of factors are taken into consideration, such as the corporate cost of capital in respect of both own and debt capital (Weighted Average Cost of Capital, WACC), the risks of the given project, the inflation impacts and other, industryspecific systemic risks. Accordingly, in the practice of enterprises the determination 
(in fact, the estimation) of the discount rate moves within relatively broad limits, depending on the size and capital structure of the company, the return on equity expected by the investors, the disposable liquid assets, as well as on the aptitude or strategic short-sightedness of the management (Jagannathan et al. 2016), and also on the common procedures in the respective country or what the respective decision-maker deems appropriate (cf. Szücs 2014).

\subsection{Social discount rate}

It is necessary to determine the social discount rate, because there are long-term investments that are important for society's long-term welfare or during the production of various public goods. The financial valuation of these with the usual discount rate established for private investments returns negative net present value, although their social net present value is positive (Tabi 2012).

Usually, four methods are applied for the definition of the discount rate used in the cost-benefit analysis performed for social investments.

- The social time preference rate (STPR) shows the size of the future yield for which the society is willing to postpone its present consumption.

- The calculation of the social opportunity cost (SOC), which reflects the costs of money markets (Tabi 2012; Tabi - Csutora 2011), comparing the two situations when the capital destined for the investment is used in the private or public sector.

- The discount rate of those projects can be calculated with the use of the weighted average (WAM) where both the private and the public sectors are involved. This is the weighted average of the social time preference rate and the social opportunity cost.

- The shadow price of capital (SPC) is the full price of the resource, also containing the external impacts. This tries to price the profit generated by the respective investment for the entire society, e.g. by preventing a kind of pollution, flood, etc. (Liu 2011).

Of these methods, the shadow price of capital and the social opportunity cost are clearly descriptive methods. Normative attempts can be observed for the definition of the social time preference rate, as it will be presented when we discuss the Ramsey formula.

\subsection{Expert enquiries}

Weitzman $(1998,2001)$ elaborated a method - later referred to as gamma discounting - to resolve the contradictions related to the discounting of projects useful for society, which has gained ground in the social project valuation of several countries. In the distant future, the degree of all factors influencing the 
discount rate, and thus the degree of the growth rate as well, is uncertain. The further away the future is, the smaller discount rate is proposed by Weitzman, i.e. the discount rate is not constant, but rather changes by periods. In fact, by using a declining discount rate (DDR) this approach tries to adjust the mathematics of discounting. By using lower or even close to zero discount rate for longer periods, it can be avoided that the future values become very small and thereby negligible. Weitzman substantiated the definition of the discount rate by expert enquiry (Freeman - Groom 2015).

\subsection{Evaluation of the procedures used for the definition of the descriptive discount rate from an ethical point of view}

Clearly, establishing the weight used for considering the effect of our actions on future generations is essentially a question of ethics. Those using descriptive methods seemingly circumvent this problem, but even with this they proclaim that their preference is the status quo, i.e. the situation is good when it somehow corresponds to the present and future deducible from the historic trends. According to this approach, the discount rate must be somehow aligned with the interest rate level currently observed in the capital markets or with future, expected interest rate level connected to historic trends, with return expectations, values calculated based on some sort of market prices, or perhaps with the discounting patterns of human agents.

Several arguments can be brought forward against the descriptive position. The first counter-argument highlights the epistemological constraints of the descriptive method - how to define the method of determining the descriptive discount rate in a "normative way", if even the participants of the economy do not know what would be "optimal", since in fact it changes from company to company or from project to project even in the same market environment (Szücs 2014; Jagannathan et al. 2016).

If the social discount rate is determined on the basis of the discounting practice used in the competitive market for projects with short-term horizons, it raises additional methodological questions. The models based on which the descriptive discount rate is established overly simplify the real business and social processes. These results are used e.g. in Great Britain or in France in a normative way for real investment calculations (HM Treasury 2003). The most disputable part of the simplification is that they often make no distinction between investments in private goods and public goods. Thus, the models implicitly assume that the allocated resources are mutually replaceable with each other (pl. Weitzman 2012, Groom et al. 2007). However, investments in public goods and private goods cannot be analysed based on the same profitability criteria, since a large part of the "utility" generated through investments in public good cannot be measured and is connected to the risk averse attitude, the absence of which may lead to the decay of the entire 
society. Although we can try to measure the utility of the efforts to reduce air pollution by tabulating the costs of the treatment of illnesses thus avoided, in this case we do not consider the better general conditions and "quality of life" of those not falling ill directly, or the habitats that are not devastated, for example by acid rain. Dams must be adjusted to the highest water-level of the last one-hundred years even if precipitation decreases in the future and the likelihood of a very large flood is small. The future "utility" generated through the cash flows invested in the production of private goods, which can be measured by monetary incomes, cannot be compared with the "utility" generated by investments for the production of public goods, which often span over generations. Despite the above seemingly reasonable arguments, the separation of public goods and private goods becomes increasingly difficult in practice. Education, healthcare and defence - usually listed as the classic public goods - today increasingly tend to be classified as private goods. Whether a particular goods, e.g. clean air, is regarded as public or private goods, today is mostly based on social consensus (Malkin - Vildavsky 1991). While in China it is only the middle class that can afford clean air in Beijing by operating air purifier equipment installed in private homes, in the European Union - today still - it is a basic human right, the breach of which is sanctioned.

If we wish to set out from the discounting habits of human agents, the question is not only whose discounting habits we take into consideration and how we obtain the data and based on which principles we make conclusions with regard to a discount rate. We also need to address the problem of rationality. Hyperbolic discounting habits, when people make decisions in respect of their own life, were analysed by a large number of tests. However, these decisions differ from each other not only at the level of the individuals: they are also not consistent over time, as the reference point for discounting may change in each new moment. Hence, the conclusion that the results thus obtained cannot serve as methodological basis for rational decisions appears to be acceptable (cf. Rambaud - Torrecillas 2006). On the other hand, it is also not acceptable in ethical terms, if in the course of influencing the present and future society we use a method that focuses on individual selfishness instead of the interests of society. This latter statement is based on the ethical maxim, according to which the economy must serve society (Odum 1983; Tainter 1988), and when making technological investment decisions, the most important factor to be considered is the long-term survival of mankind (Jonas 1984).

The "normative application" of the descriptive rate alone raises a severe philosophical problem, which is dealt with by Hume's law. Hume (1739) notes that deducting "what ought to be" from "what is" in fact is a methodological error, since the moral commands thus obtained lack a suitable logical basis. Hume's law also serves as methodological basis for ethical analyses. Accordingly, the application of descriptive discounting not only has epistemological constraints, as there are also 
ethical reasons against making the application of a currently postulated discount rate based on any particular observation mandatory in long-term projects with an effect on the unforeseeable future.

\subsection{Discount rate determined on the basis of ethical considerations}

The ethical frameworks are differentiated on the basis of the decision rules used for deciding what is good and what is bad. The two most important classic ethical schools are deontology and consequentialism. Both of these ethics focus on human acts and the evaluation thereof. In the case of deontology, the emphasis is on the intention of the acting agent, since at the moment of the decision we do not know what the consequence of the act will be. In the case of intertemporal decisions, deontology does not offer a proper practical basis for valuation. The decision rule of the deontology is generalisation. The perception of good and bad is based on whether there is a general moral maxim, applicable to all, which can be used in the given situation (Kant 1995). In the case of discounting, it is difficult to imagine such a norm, to be observed under any circumstances (categorical imperative). Although the philosophers researching the principles of deontology do deal with our responsibilities towards other living creatures or people living in the future, this is primarily a static philosophy that is unable to manage events of a long time horizon, which may also impact several generations, as it focuses on the moment of decision (Hampicke 2011).

On the other hand, according to the consequentialism, it is the consequence of the action rather than the intention, of which we may make an ethical judgement, i.e. declare it good or bad. In consequentialism, we can specify a variety of benchmarks and measure the consequence depending on whether the freedom of the society or the stakeholders increases or decreases (Gaus 2012). We can examine how the respective action affects the happiness of the individual, the stakeholders, the entire society or all people living and to be born (Sinnot-Armstrong 2015). It is no accident that, in terms of ethical frameworks, it is the concepts of consequentialism that we can rely on when examining how today's decisions impact future generations. The ethical judgement as to whether discounting and the selection of the discount rate is good or bad can be pronounced based on the future consequences of the investments deemed viable by today's discounting methods, i.e. how today's generations and future generations share the burdens and the benefits (Broome 1994; Sen 1973).

Of the schools of utilitarianism, which belongs to consequence-based ethics, classic cardinal utilitarianism and discounted utilitarianism deal with discounting (Gollier 2011; Greaves 2017). Cardinal utilitarianism assumes that joy and utility, the economic equivalent of joy, are measurable and can be expressed as individual preferences (e.g. Jevons 1911). Harsányi (1955) explains that individuals are able to compare the utility realisable through certain choices also between each other, 
and the basis of such comparison is the inductive arguing based on facts, rather than a subjective feeling based on some kind of psychological basis. Discounted utilitarianism and the various schools thereof already more or less make allowances for conflicts of interest between different generations (Greaves 2017), with Ramsey being one of the very first advocate of this.

Setting out from the utilitarian positions dealing with discounting, we can arrive at two completely contradicting results: according to classic cardinal utilitarianism discounting must be avoided, thus for example in the context of climate change we should renounce our present consumption to ease the burden of future generations. According to discounted utilitarianism, discounting is our moral obligation and we should hardly deal with the future and particularly with our descendants in the distant future (Greaves 2017). In the following, we present through the analysis of the Ramsey formula the considerations that may lead to these two opposite ethical positions.

\section{The Ramsey formula}

The baseline of the discussion related to long-term discounting, applicable to the unforeseeable future - which caused increasing excitement from the end of the 1960s - is Ramsey's 1928 paper on the mathematical theory of savings (for a summary of the dispute, see e.g. Arrow et al. 2012; Gollier 2011). This paper focuses on the question how much a society needs to save to maximise its welfare for a very long time, i.e. "forever". Ramsey's model sets out from a closed society, first created by a single immortal consumer, who controls the factors of production and consumes the produced goods on his own, and would like to save as much that ensures maximum utility both in the present and in the future. To achieve this, he must keep marginal utility at a constant level, i.e. in the case of consuming each new unit of product the same utility must be attributed to consumption. For this very reason, one of Ramsey's benchmark assumptions is that during consumption marginal utility does not grow to infinity, but rather converges to a certain limit (the greatest happiness achievable). Later on, Ramsey resolves the concept of

single consumer, and impersonates this in successive generations, when the single individuals are concerned with their own and their heirs' profit.

In the model, Ramsey differentiates the discounting of utility and the discounting of cash flows. While in the latter case the discount rate corresponds to the interest rate, in the case of utility various people may have different utility concepts, and this heterogeneity is reflected by the size of the discount rate applied to the utility. Ramsey talks about a society, essentially divided into two groups, where people - or rather the immortal families - will become rich or poor depending on their patience or their capability of renouncing current consumption to invest the savings so accumulated. 
From Ramsey's model the rate applied to the discounting of cash flows (rather than the individual utilities), i.e. the desirable interest rate level, can be deduced from the following equation, referred to as the Ramsey formula:

$$
r=\delta+\eta g
$$

Where the rate in the given moment of time is determined by three factors:

- $\delta=$ pure social time preference rate

- $\eta$ = elasticity of marginal utility with respect to consumption

- $\mathrm{g}=$ growth rate of consumption per capita.

The size of $r$ so determined returns the interest rate level expected from the investment financed from savings, and which ensures the maintenance of social welfare in the case of the intertemporal decisions. Accordingly, in order to maximise utility in the present and future society, we need to use the same value also as the discount rate (Greaves 2017).

The Ramsey formula is often used for the valuation of investments that the society is compelled to make in order to preserve its welfare in the future as well, but do not offer a return under market circumstances. Thus the Ramsey formula substantiates the already mentioned, widely used method of determining the social discount rate. The $r$ - renamed as social time preference rate (STPR) - shows the amount which the present society is willing to renounce in order to ensure the consumption of future generations (Tabi - Csutora 2011).

The definition of the individual parameters of the Ramsey formula reveals the individuals' ideas of the future and whose interests they consider in making intertemporal decisions.

\subsection{Pure social time preference}

Pure social time preference is the parameter in respect of which there are a variety of opinions. Today this parameter is interpreted as the "measure of the impatience" of successive generations (Tabi - Csutora 2000), indicating to what degree we are willing to renounce current consumption to the benefit of the future generation. By contrast, Fisher (1930) believes that the impatience of the society and/or of the individual is expressed by the complete Ramsey formula. The pure social time preference is to be combined with the expected growth per capita, which - according to the classic theory - leads to a decrease in the marginal utility of consumption.

The above interpretation of the pure social time preference detracts from Ramsey's original definition. Ramsey interprets pure social time preference as the function 
of utility rather than of the cash flow (Ramsey 1928:288). This parameter is zero for Ramsey, because it is not possible to compare the utility of people living in different periods or, in the context of single individuals, the utility perceived today with the utility perceived later. For this reason, it is not acceptable in ethical terms if preference is given to the utility of any generation over the other.

While Ramsey's view that the value of the pure social time preference is zero is based on epistemological presumption, later authors (e.g. Cline 1992; Dasgupta 2008; Gollier 2011) explain this by impartiality and the equality of generations, as utility should not be differentiated depending on when and which generation enjoys it. Let us think of the utility provided by public goods, such as clean air, forests or unpolluted rivers. It should be mentioned that Stern (2006) also believes that we must not put our welfare before that of future generations. Thus, the result of the zero social time preference is that only growth and the marginal utility of consumption influence the discount rate.

What could be the arguments for a positive pure social time preference rate, i.e. for putting today's utility before that of the future? That is, what could justify the lack of impartiality in the case of intertemporal decisions? The most obvious argument is that we are going to die, and since this increases the possibility of not benefiting from the future utility created through our savings, we should ultimately give our own generation preference. This argument can be substantiated based on the principle of maximising the utility between the single individuals. The pure time preference rate adjusted for life expectancy increases the parameter's value by the mortality ratio. If life expectancy deteriorates, it increases the value of the time preference, while if it improves, it reduces it (Pearce-Ulph 1995).

According to the second argument, ensuring the welfare of the successive generations requires us to make huge sacrifices. According to Arrow (1999), all generations are selfish, and for this reason we cannot expect them to renounce their present consumption for the benefit of the next (also selfish) generation, to maximise the utility of all generations succeeding them. Although this does not preclude the consideration of the next generations' interests, it results in a pure time preference rate higher than zero. If we think about an investment that produces profit in the long run, spanning over generations, such as e.g. - according to Arrow (1999) - the Hoover dam, the generations that enjoy the benefits of this investment are put at an advantage over the members of the generation from the savings of which the investment was financed. Those who enjoy the benefits provided by the dam later may even decrease the degree of their own savings, and thus they are put at an advantage over the previous and the next generations. This train of thoughts is in line with the utilitarian approach, as the retaliation applied upon the individual generations (in the form of discounting) within the given framework, makes an 
attempt to reduce their benefit deriving from selfishness and thus it spreads the utility among more people, making the distribution thereof more even.

\subsection{Elasticity of marginal utility with respect to consumption}

The elasticity of marginal utility with respect to consumption reflects that we assess the utility of each future additional unit of consumption depending on our own welfare. Expressed in cash flows: receiving 100 forints means much less for a rich man than for a poor one. Since this is a ratio, if the elasticity of the marginal utility is 1 , one per cent additional consumption will generate the same utility both for the poor and the rich man. (Of course, when expressed in absolute value, the values differ; each additional consumption of 1 forint represents the same utility for a poor man with 100 forints, as the additional consumption of 10 forint for a rich man with 1,000 forints.) If this ratio exceeds 1 , it means that it brings less profit for the rich man if his consumption grows by as many percents as that of the poor man. This correlation is Gossen's law on the decreasing marginal utility, and in fact is an axiomatic general condition, which is usually illustrated by analogies such as: if I already have a house/apple, car etc. in the future I will have much less benefit if I get one more of that than if I did not have it, and thus it is unlikely that it makes sense to save today to enjoy the benefit thereof in the future. This axiom appears to be plausible in the case of consumer goods within a single generation, i.e. in respect of the decisions of an individual determining his own future.

If the value of the consumption marginal utility exceeds one, it means that - if the other factors are constant and growth is positive - the discount rate will be higher. Thus, this parameter can be also interpreted as a guarantee for the equal distribution between present and future consumption, which shows the degree of intertemporal inequality aversion (Gollier - Hammit 2014). According to Arrow et al. (2004), this parameter ensures equitableness between generations.

There are intertemporal decisions that determine the future state of nature for example and reduce the effect of climate change. Why would it represent a smaller benefit for a rich man than for a poor one if the extinction of certain species of animals or plants, e.g. polar bears, can be prevented (Frederick 2006)? The rich are usually much more willing to support such projects than the poor. Based on the analogy of the above train of thought, it would also follow from this that for them it represents higher utility if they can benefit from the natural resources in the future as well, than for the poor (Revesz - Shahabian 2011). Thus, if we prefer present consumption instead of investing in projects that preserve the services provided by nature, it is possible that the future generation will appreciate scarce and disappearing natural resources much more than we do at present, and thus in the case of such projects the parameter must be less than on in the case of positive growth per capita in order to reduce the value of the discount rate. 


\subsection{Growth rate of consumption per capita}

The seemingly most exact parameter of the Ramsey formula is the growth rate of consumption per capita. If we ignore the other parameters, i.e. the value of the pure time preference rate is zero and the elasticity of marginal utility of consumption is one, the discount rate is determined solely by the growth rate.

Economists usually assume a positive growth rate in the long run. The source of growth is capital accumulation and technological change (Pearce - Ulph 1995). Based on retrospective data, going back $100-180$ years, this value is estimated for Great Britain to be 1.3-1.6 (OXERA 2002). If we accept this value also in relation to the future long-term growth rate, it is easy to justify the discounted utilitarianism. Since our objective is to ensure the optimal - i.e. most even - distribution of the benefit of the investment between the generations, discounting is unavoidable. Without discounting, the present generations renounce their consumption to ensure that the future generations which become rich through the growth of the economy become even richer. As it is noted by Baumol (1968), this is a "reverse Robin Hood" measure, as in 100 years the average income per capita may be several times higher (in real terms) than today, so why should we renounce part of our income to give it to those more affluent than us.

On the other hand, if the growth rate is zero, we have no right to discount, since with discounting we make the future generations poorer. According to Broomer (1994), a believer in cardinal utilitarianism, particularly in the context of climate change discounting cannot be justified, as the impacts thereof will be mostly felt by the poor countries. Those who are more willing to invest today in the reduction of the emission of greenhouse gases, are the rich countries with developed industry, while the poor, underdeveloped countries that will feel the impact of climate change the most, will be poorer even in the future than today's developed countries.

The dispute between the two opinions (cf. e.g. Sen 1973 and Pearce - Ulph 1995) is not the result of the questioning of the utilitarian principles based on equality and impartiality, but rather of the different construction of the authors' world model. While Sen (1973) deems the individual generations to be homogenous, Broome (1994) expands the issue of discounting over generations with the inequalities within the generations. If both the present and future generations comprise of the poor and the rich, it is indeed questionable how today's rich relate to the future's poor. This problem appears even if economic growth is positive. If we make major investments that relieve the future generation of the impacts of climate change, we have two options: withdraw the necessary funds from the poor or from the rich. If from the rich, the argumentation of Broome (1994) may be valid. But if the price of these investments is that we spend less for the elimination of the inequalities within the generations due to reducing the investments and aids in the individual countries and those directed to the developed countries, the reference to reverse 
Robin Hood becomes valid. Namely, in the future generations the poor will become less poor by exploiting the less affluent members of the present generations.

However, if the growth rate of the consumption per capita is negative, there will be an interesting situation where the discount rate becomes negative. However, the literature deals with this possibility only marginally. According to Weitzman (2009), in those cases when there is a very high risk of an imminent disaster, it is justified to use all resources of the present for the prevention thereof. In the model where he proves this thesis, he examines consumption as a function of the rising temperature of the Earth. If we examine the hypothetical situation when due to the extremely high temperature consumption falls to the minimal, the negative discount rate should also converge to the infinite.

Whether GDP is an appropriate measure of the long-term growth or "social utility" - not to mention happiness - generates rather strong disputes. Extreme weather conditions, disasters, floods and forest fires, which are becoming increasingly frequent in the course of climate change, and the dramatic fall in the growth rate of the agricultural average yields observed in the long run, accompanying the rise in temperature (Ray et al. 2013; Hatfield 2016) suggest that the economists' belief in continuous and technological growth will sooner or later will come up against natural barriers. While in the past period monocultures, the use of chemicals, genetically modified organisms and agricultural technologies forcing back nature to smaller and smaller fragmented territories contributed to the growth in GDP, between 1998 and 2013 the production potential of these areas decreased substantially, by roughly 20 per cent (GLO 2017). As a result of urbanisation, the changed use of land, and at the same time making a fetish of GDP growth, there may be nothing left for the future generation to measure.

\section{Evaluation of utilitarian discounting}

Although cardinal and discounted utilitarianism are seemingly antagonistic to each other, in fact this antagonism is connected to the different expectations with regard to the future and the often opposite assumption related to economic agents. The benchmark assumptions of the models include the rational, profit maximising agent, which is immortal or mortal. When it comes down to mortal agents, they are clustered in successive or overlapping generations, which are either homogenous in terms of capital distribution and consumption, or can be divided into the rich and the poor.

The normative position precludes the differentiation of generations: that is, we prefer the present to the future (cardinal utilitarianism) or the future to the present (discounted utilitarianism). Setting out from this position, the decline in the marginal utility of consumption can be questioned in the same way when it 
comes to the valuation of public goods, the nature or the environment, rather than to the consumption of private goods. The concept of "greatest happiness" is usually identified with "utility" in the utilitarian literature on discounting. This substitution represents a major leap between the absolute, numerically not measurable, concept of happiness and the utility notion, which can be quantified, at least in theory by various methods. The identification of happiness (described by Ramsey as the perfect but unattainable "bliss") with the utility achievable during consumption is a fundamental logical error. Muddling the "utility" of the services provided by nature with the utility of consumption is the same sort of error.

In summary, we can state that the seemingly controversial results of utilitarian ethical analysis are attributable to the different interpretations of utility and/or the different estimation of the various parameters, primarily the future growth rate, impacting the discount factor.

\subsection{How to discount?}

For the discount rate applied in the case of investments important for society, a wide range of values are determined in the world. At present, in the USA discount rates of 3 and 7 per cent both apply to public projects (CEAI 2017), in Norway it is 2.5 per cent for risk-free projects, declining to 1 per cent after 41 years, while in the Netherlands the discount rate is 0 per cent for the risk-free projects, and these rates are adjusted by the risk premium as necessary (Groom 2017). The discount rate applied in developing countries may be as high as 10-12 per cent, e.g. in Serbia it is 10 per cent (Djukic et al 2016). The different values are determined on a descriptive or prescriptive basis, or sometimes the discount rate that facilitates the implementation of the respective project is simply adjusted to political decisions (Groom 2017).

Having reviewed the procedures and philosophies determining the discounting methods, we found that neither utilitarian normative discounting nor observationbased descriptive discounting (or some sort of combination of the two) resolves the ethical problems related to the discount rate to be applied in the case of intertemporal projects and they give no guidance to be followed with regard to the ultimate discount rate. However, the failure of utilitarian discounting does not mean that we need to give up the ethical dimension. If we choose human societies or even the entire mankind rather than the individual or generations interpreted as the aggregation of individual interest as the ethical benchmark shaping the general conditions of the model to be used for the definition of discounting, we may arrive at an approach that helps avoid the contradictions of the models presented in the study. The cases when we need to make a decision on the application of the social discount rate are usually long-term projects important for the entire society or even for mankind as a whole. These projects also include investments 
the implementation of which is financed by the private sector, but in the future will substantially burden the environment.

In practice, this involves how to treat a development related to a risky technology or projects aimed at protecting the environment. One of the obvious possibilities to address these cases is the application of two types of discount rates: when it comes to investments where damages caused to the future generation should be prevented, no discounting should be applied, while in all other cases the determination of the discount rate should be left to the market (Davidson 2014). (Of course, we do discount even when no discounting is applied, but in this case the discount rate is zero.) Another possibility, in addition to discounting, is to take measures that help reduce the burdens of future generations. These measures should be taken by society or it should force private investors to take them. These may be requirements, already introduced in certain areas, which e.g. increase the costs of a mine opening due to the requirement to deposit collateral for the costs of recultivation, or measures when the respective society invests in research to reduce the environmental effects of a harmful technology, as well as the research and constructions related to the high-level radioactive waste disposal of a nuclear plant. No matter which of the above possibilities is implemented, we never know in advance whether we comply with the principle of utilitarianism, i.e. have we not favoured the present or future generations. This assessment, if it is possible at all to measure the utility generated by a public investment, always takes place ex post, while upon planning the investments we need to focus on the future ex ante, without knowing what will follow.

If we do not want to become resigned to our ethical impotence, it is worth looking for ethical arguments which focus on the future of human society rather than trying to reconcile the economic theory and the ethical opinion (Davidson 2014). The ethics of responsibility, as defined by Jonas (1984), states that the most important ethical command for all generations is to ensure the survival of mankind in such a way that future generations can also live a worthy life on Earth. When it comes to potentially hazardous technologies, we must not ignore the risks they represent in such a way that we increase the amount of the damage caused by a disaster, catastrophe or extraordinary event by the risk of the occurrence. It follows from this that we should forego the technologies the impact of which jeopardises the vital conditions of future generations. What is the consequence of this in terms of discounting? If we insist on the cost-benefit analysis, Weitzman's (2009) negative discount rate must be used for these technologies, which also assumes that we do not believe that the future society will be able to eliminate the environmental damages that we leave to them. Eastern Europe or Hungary are good examples of this, where the rehabilitation of the environment damaged by the socialist industry has not taken place to date; just think about the hazardous waste in Garé or that 
the recultivation of the refuse dump left over by the uranium mines was financed - in the absence of suitable domestic resources - by the European Union's preaccession fund, the PHARE programme. These examples also show that we must not assume that future generations will be richer than us, as we exhaust and degrade the natural resources and environment through human activity in such a way that provides much worse general conditions for the future generation than those we live in today.

The presently used discounting methods and discount rates cannot be applied for deciding on the type of investments that can ensure the right of future generations to a clean environment and nature, and thereby to human dignity. Both the theoretical and practical problems indicate that in the future some kind of different discounting philosophy or different type of cost-benefit analysis method should be elaborated for the valuation of public investments. For this purpose, we may rely on - in addition to the responsibility of ethics of Jones, mentioned above - the philosophy of Rawls (1985), which focuses on fairness. If we fairly distribute the benefits and burdens between the individual generations rather than focusing on the utilitarian approach of utility, where we chase the "greatest happiness" (Bentham 1907), we change over to a different paradigm of thinking. In this paradigm the minimisation of damages may be more important (Popper 1952:304) than the maximisation of welfare. The role of discounting in such a costbenefit analysis, introducing fairness as an axiom, is not yet clear. The elaboration of this in the form of policies also implementable in practice may be a research area for the future.

\section{Summary}

Discounting is apparently a financial technical operation, but in fact determining the discount rate is based on serious ethical and economic philosophic considerations. This is particularly true when it comes to discounting the cash flows of costbenefit analyses used for investments important for the society. In this paper, we summarised the most important trends in the literature on ethics related to discounting. We found that the descriptive discount rate, observing the individuals' discounting habits or the behaviour of the agents of the private economy, is questionable both in terms of epistemology and ethics. The reason for this is that the determination of the rate is rather subjective even in the private economy. On the other hand, with the ethical assessment we run into Hume's guillotine, which states that what we have now is not necessarily good as well. In the case of the prescriptive approach, the most common utilitarian approach sets out from the need to ensure fair distribution between the present and future generations by discounting. We examined certain aspects of the utilitarian approach relying on the Ramsey formula. We found that of the parameters specified by Ramsay, the 
contradictions characterising the cardinal and discounted utilitarianism arise from the different interpretation of utility and the different estimation of the future growth rate. Namely, according to the cardinal utilitarianism we must not discount, while according to the discounted utilitarianism we must discount, if we want to ensure the welfare of both present and future generations. Finally, the paper deals with the discount rates applied in practice in the case of social investments, upon the substantiation of which both the descriptive and the prescriptive principles are relied on in the individual countries. This diversity, together with the most important - often contradicting - recommendations of the reviewed literature, show that the present discounting methods distort the cost-benefit analysis of the investments important for society.

\section{References}

Arrow, K.J. (1999): Discounting, morality, and gaming. In: Portney, P.R. - Weyant, J.P. (Eds.): Discounting and intergenerational equity. Washington: RFF Press, pp. 13-21.

Arrow, K. - Dasgupta, P. - Goulder, L. - Daily, G. - Ehrlich, P. - Heal, G. - Levin, S. - Maler, K.G. - Schneider, S. - Starrett, D. - Walker, B. (2004): Are we consuming too much? Journal of Economic Perspectives, 18(3): 147-172. https://doi.org/10.1257/0895330042162377

Arrow, K. - Cropper, M. - Gollier, C. - Groom, B. - Heal, G. - Newell, R. - Nordhaus, W. Pindyck, R. - Pizer, W. - Portney, P. - Sterner, T. - Tol, R. - Weitzman, M. (2012): How should benefits and costs be discounted in an intergenerational context? The views of an expert panel. Discussion Paper, Resources for the Future: 12-53.

Baumol, W.J. (1968): Welfare Economics and the Theory of the State. Harvard University Press, Cambridge, MA. p. 800.

Bélyácz, I. (2010): Kockázat vagy bizonytalanság? Elmélettörténeti töredék a régi dilemmáról (Risk or uncertainty? Theoretical excerpt on the old dilemma). Közgazdasági Szemle, 57(July-August): 652-665.

Bentham, J. (1907): Introduction to the principles of morals and legislation. London: Oxford Clarendon press. http://fs2.american.edu/dfagel/www/Philosophers/Bentham/ principlesofMoralsAndLegislation.pdf. Downloaded: 24 October 2017.

Broome, J. (1994): Discounting the Future. Philosophy \& Public Affairs, 23(2): 128-156. https://doi.org/10.1111/j.1088-4963.1994.tb00008.x

BWE (2015): Gutachtliche Stellungnahme zur Bewertung der Rückstellungen im Kernenergiebereich (Expert Opinion on the Valuation of Provisions in the Nuclear Power Industry). https://www.bmwi.de/Redaktion/DE/Downloads/S-T/stresstestkernenergie. pdf?_blob=publicationFile\&v=3 
CEAI (2017): Discounting for Public Policy: Theory and Recent Evidence on the Merits of Updating the Discount Rate. Council of Economic Advisers Issue Brief January 2017. https://obamawhitehouse.archives.gov/sites/default/files/page/files/201701_cea_ discounting_issue_brief.pdf. Downloaded: 24 October 2017.

Cline, W.R. (1992): The economics of global warming. Washington, D.C.: Institute for International Economics.

Dasgupta, P. (2008): Discounting climate change. Journal of risk and uncertainty, 37(2): 141-169. https://doi.org/10.1007/s11166-008-9049-6

Davidson, M.D. (2014): Zero discounting can compensate future generations for climate damage. Ecological Economics, 105: 40-47. https://doi.org/10.1016/ j.ecolecon.2014.05.018

Djukic, M. - Jovanoski, I. - Ivanovic, O.M. - Lazic, M. - Bodroza, D. (2016): Cost-benefit analysis of an infrastructure project and a cost-reflective tariff: A case study for investment in wastewater treatment plant in Serbia. Renewable and Sustainable Energy Reviews, 59(June): 1419-1425. https://doi.org/10.1016/j.rser.2016.01.050

Fisher, I. (1930): The Theory of Interest. New York: Kelley and Millman.

Frederick, S. (2006): Valuing Future Life and Future Lives: A Framework for Understanding Discounting. Journal of Economic Psychology, 27(5): 667-680. https://doi.org/10.1016/ j.joep.2006.05.007

Freeman, M.C. - Groom, B. (2015): Positively gamma discounting: Combining the opinions of experts on the social discount rate. Economic Journal, 125(585): 1015-1024. https://doi.org/10.1111/ecoj.12129

Gaus, G. (2012): The Order of Public Reason: A Theory of Freedom and Morality in a Diverse and Bounded World. Cambridge: Cambridge University Press.

GLO (2017): United Nations Convention to Combat Desertification. 2017. The Global Land Outlook, first edition. Bonn, Germany.

Gollier, C. (2011): Pricing the future: The economics of discounting and sustainable development. Princeton University Press, pp. 1-210.

Gollier, C. - Hammit, J.K. (2014): The Long-Run Discount Rate Controversy. Annual Review of Resource Economics, Vol. 6: 273-295. https://doi.org/10.1146/annurevresource-100913-012516

Greaves, H. (2017): Discounting for Public Policy. A Survey. Economics and Philosophy, 33(3): 391-439. https://doi.org/10.1017/S0266267117000062 
Groom, B. - Koundouri, P. - Panopoulou, E. - Pantelidis, T. (2007): Discounting the distant future: how much does model selection affect the certainty equivalent rate? Journal of Applied Econometrics, 22(3): 641-656.

Groom, B. (2017): International Guidelines on Social Discount Rates. http://www.strategie. gouv.fr/sites/strategie.gouv.fr/files/atoms/files/07_ben_groom_international_guidelines_ on_social_discount_rates.pdf. Downloaded: 24 October 2017.

Hampicke, U. (2011). Climate change economics and discounted utilitarianism. Ecological Economics, 72: 45-52. https://doi.org/10.1016/j.ecolecon.2011.08.028

Harsányi, J. (1955): Cardinal Welfare, Individualistic Ethics, and Interpersonal Comparisons of Utility. Journal of Political Economy, 63(4): 309-321. https://doi.org/10.1086/257678

Hatfield, J.L. (2016): Increased Temperatures Have Dramatic Effects on Growth and Grain Yield of Three Maize Hybrids. Agricultural \& Environmental Letters, 1(1), 150006.

HM Treasury (2003, updated July 2011): The Green Book - Appraisal and evaluation in central government. London.

Hume, D. (1739): A Treatise of Human Nature. https://people.rit.edu/wlrgsh/HumeTreatise.pdf Jagannathan, R. - Matsa, D.A. - Meier, I. - Tarhan, V. (2016). Why do firms use high discount rates? Journal of Financial Economics, 120(3): 445-463. https://doi.org/10.1016/ j.jfineco.2016.01.012

Jevons, W. (1911): The Theory of Political Economy. Macmillan, London.

Jonas, H. (1984): Das Prinzip Verantwortung. Versuch einer Ethik für die technologische Zivilisation (The Principle of Responsibility. Towards an Ethics for Technological Civilisation). Frankfurt a.M.

Kant, I. (1995): Kritik der praktischen Vernunft (Critique of Practical Reason). Reclam. Stuttgart.

Knight, F.H. (1921): Risk, Uncertainty, and Profit. Hart, Schaffner \& Marx-Houghton Mifflin Co., Boston, MA.

Lewandowsky, S. - Freeman, M.C. - Mann, M.E. (2017): Harnessing the uncertainty monster: Putting quantitative constraints on the intergenerational social discount rate. Global and Planetary Change, 156(September): 155-166. https://doi.org/10.1016/ j.gloplacha.2017.03.007 
Liu, L. (2011): From the Shadow Price of Capital to the Marginal Cost of Funds: In Search of the Implementation of a Principle. Journal of Public Economic Theory, 13(3): 369-389. https://doi.org/10.1111/j.1467-9779.2011.01504.x

Malkin, J. - Vildavsky, A. (1991): Why the Traditional Distinction between Public and Private Goods Should be Abandoned. Journal of Theoretical Politics, 3(4): 355-378. https://doi.org/10.1177/0951692891003004001

Nordhaus, W. (2006): The "Stern Review" on the Economics of Climate Change. Journal of Economic Literature, 45(3): 686-702. https://doi.org/10.3386/w12741

Nordhaus, W. (2008): A Question of Balance: Weighing the Options on Global Warming Policies. Yale University Press.

Odum, H.T. (1983): System Ecology an Introduction. J. Wiley, NY.

OXERA (2002): A Social Time Preference Rate for Use in Long-term Discounting. Oxera Consulting Ld. p 80.

Pearce, D. - Ulph, D. (1995): A social discount rate for the United Kingdom. Working paper No 95-01, CSERGE, University College London, and University of East Anglia, pp. 1-22.

Popper, K.R. (1952): 1st Edition The Open Society and Its Enemies, Volume II, 1st Edition. Routledge \& Kegan Paul, London. https://monoskop.org/images/6/6d/Popper_Karl_ The_Open_Society_and_its_Enemies_The_High_Tide_of_Prophecy_Vol_2_1st_ed.pdf. Downloaded: 24 October 2017.

Rambaud, S. - Torrecillas, M.J.M. (2006): Social discount rate: a revision. Anales de Estudios Económicos y Empresariales, XVI: pp. 75-98. http://dialnet.unirioja.es/servlet/ articulo?codigo=2315261. Downloaded: 24 October 2017.

Ramsey, F.P. (1928): A mathematical theory of saving. Economic Journal, 38(152): 543-559. https://doi.org/10.2307/2224098

Ray, D.K. - Mueller, N.D. - West, P.C. - Foley, J.A. (2013): Yield Trends Are Insufficient to Double Global Crop Production by 2050. PLoS ONE 8(6): e66428. pp. 1-8. https://doi.org/10.1371/journal.pone.0066428

Rawls, J. (1985): Justice as Fairness: Political not Metaphysical. Philosophy and Public Affairs, 14(3): 223-251.

Revesz, R.L. - Shahabian, M.R. (2011): Climate change and future generations. Southern California Law Review, Vol. 84: p. 1097.

Sen, A.K. (1973): On Economic Inequality. Clarendon Press, Oxford. https://doi.org/10.1093/0198281935.001.0001 
Sinnot-Armstrong, W. (2015): Consequentialism. In: Zalta, E.N. (ed.): The Stanford Encyclopedia of Philosophy. Winter 2015 Edition.

Stern, N. (2007): The Economics of Climate Change: The Stern Review. Cambridge University Press. https://doi.org/10.1017/CBO9780511817434

Szúcs-Markovics, K. (2014): A kalkulativ kamatláb (diszkontráta) meghatározásának ajánlott és alkalmazott módszerei (Recommended and applied methods of determining the calculative interest rate (discount rate)). Controller info, 2(4): 8-13.

Tabi, A. (2012): A társadalmi diszkontráta jelentősége a fogyasztás időbeli ütemezésében (Importance of social discount rate in the scheduling of consumption). In: Fenntartható fogyasztás? Trendek és lehetőségek Magyarországon (Sustainable consumption? Trends and opportunities in Hungary) - Results of OTKA research 68647 AULA, Budapest, pp. 142-173.

Tabi, A. - Csutora, M. (2011): A temporális diszkontálási szokások vizsgálata - a társadalmi diszkontráta és a társadalmi preferenciák kapcsolata (Analysis of the temporal discounting habits - Correlation between the social discount rate and social preferences). p. 19. http://unipub.lib.uni-corvinus.hu/495/1/tarsdiszkont_Tabi_Csutora20110610.pdf

Tainter, J.A. (1988): The Collapse of Complex Societies. Cambridge University Press.

Trostel, P.A. - Taylor, G.A. (2001): A theory of time preference. Economic Inquiry, 39(3): 379-395. https://doi.org/10.1093/ei/39.3.379

Weisbach, D. - Sunstein, C.R. (2009): Climate change and discounting the future: a guide for the perplexed. Yale Law and Policy Review, 27: 433-458.

Weitzman, M.L. (1998): Why the far-distant future should be discounted at its lowest possible rate? Journal of Environmental Economics and Management, 36(3): 201-208. https://doi.org/10.1006/jeem.1998.1052

Weitzman, M.L. (2001): Gamma discounting. American Economic Review, 91(1): 260-271. https://doi.org/10.1257/aer.91.1.260

Weitzman, M.L. (2009): On modeling and interpreting the economics of catastrophic climate change. Review of Economics and Statistics, 91(1): 1-19. https://doi.org/10.1162/ rest.91.1.1

Weitzman, M.L. (2012): The Ramsey Discounting Formula for a Hidden-State Stochastic Growth Process. Environmental and Resource Economics, 53(3): 309-321. https://doi.org/10.1007/s10640-012-9594-y 